\title{
QUALITY AND COMPLIANCE IN SHORT-CYCLE HIGHER EDUCATION PROGRAMS IN THE FIELD OF REAL ESTATE MANAGEMENT
}

\author{
Intra L $\mathbf{L} \mathbf{C E}$ \\ College of Law, Riga, Latvia \\ Corresponding author e-mail: intra@jk.lv
}

\begin{abstract}
The article deals with the concept of quality and compliance in the context of the short-cycle professional higher education (SCHE) program in the field of real estate management. The article highlights the role of graduates and employers in assessing the quality and compliance and surveys of students as well. The surveys of students, graduates and employers and the analysis of legislation allow assessing the quality and compliance of SCHE study program in real estate management. Currently, in Latvia, the qualification of a house manager can be obtained at three accredited higher education institutions, studying in a short-cycle professional higher education program, which, in accordance with European Qualifications Framework (EQF), is the first-level professional higher education program. The article will mainly focus on the quality and compliance of the house managers' professional qualification acquisition in short-cycle higher education programs in Latvia. Data analysis, synthesis and logical construction methods have been used in this article.
\end{abstract}

Keywords: Compliance, education, qualifications, quality, real estate management, short-cycle higher education, study program.

\section{INTRODUCTION}

Alongside with the rapid development of the real estate market, it is necessary to pay more and more attention to the specialists in the field of real estate. In this article, the field of the administration and management of real estate in short-cycle higher education (SCHE) programs has been highlighted. Short-cycle higher education plays a significant role in turning out middle-level specialists for which there is demand in the job market. This education is characterised by a relatively short study period of 2 to 3 years. "SCHE as the first level in higher education and as level 5 of the European Qualifications Framework (EQF) has become increasingly important in the last decade. In SCHE a growing number of countries involved in the Bologna Process are giving the underlying programs a formal position in their education system, linked to a national qualifications framework" (Eurashe, 2010).

In conformity with the provisions of laws and regulations in force, namely Law on Administration of Residential Houses (2010), the administrators of real estate may be persons with proper professional qualification. Thus, education is an important aspect, and, in this case, the professional education implemented 
within higher education study programs and vocational continuing education programs shall be pointed out.

At present, in conformity with the provisions of the laws and regulations in force, as it was mentioned above, it is essential to ensure the administration of real estate by qualified professionals in this field, i. e., by both administrators and managers of houses.

The aim of the article is to reflect the quality assessment indicators of short cycle professional higher education study program in real estate management and compliance with labour market demand. The tasks set for achieving the goal are to analyse the existing legislation, the concept of quality and compliance, as well as to conduct a survey of students, graduates and employers. Data analysis, synthesis and logical construction methods have been used in this article.

\section{QUALITY AND COMPLIANCE IN HIGHER EDUCATION}

Under the globalization conditions of modern economy, the quality is being more often and more emphasized. Although, at the same time, we cannot assume that quality is a novelty nowadays, a discovery. The word "quality" has its ancient history. Quality as certain topicality has existed in the society already since ancient times, when an individual was aware of the significance of the shape, appearance, and usefulness of the object produced, developed by him.

Rather rapidly the topicality of quality started to develop in 1940s, when the theory of quality emerged. In fact, we can consider the Japanese to be the developers of the principle of quality - after the Second World War, they started to direct their policy towards the implementation of economic aims by paying particular attention to the quality in manufacturing, setting the requirement that the management of the company shall assume the responsibility for the introduction of the quality management system and the observation of its requirements, that there shall be acquired the fundamental principles of this system and shall be ensured the participation of the staff in the quality improvement process, as well as the quality improvement shall be viewed as an ongoing process.

Having studied the definition of "quality", we cannot find an unambiguous answer. The quality has been defined by several globally well-known people E. W. Deming (2017), J. M. Juran (1974), P. B. Crosby (1979), K. Ishikova - and each of them has defined quality in a slightly different manner. E. W. Deming (2017) has defined that quality means to satisfy the desires a client is aware of and yet unaware of, P. B. Crosby (1979) has defined quality as compliance to requirements, J. M. Juran (1974) has viewed it as compliance to the use, and $\mathrm{K}$. Ishikova - as a property that really satisfies the consumer.

And, finally, the quality has been also defined in two rather important documents, i. e., in ISO 9001:2000, where quality is defined as compliance to requirements, and in ISO 9001:2008 (ISO, 2008), where it is defined as a totality of the qualities of basic service/product, which can meet the set requirements.

In higher education, the measures taken for ensuring quality guarantee the quality of higher education. Higher education that is qualitative and meets the 
needs of labour market provide students with knowledge, skills, and transfer competence they need in order to gain success after they have received their diplomas. It is provided in the qualitative study environment, where good teaching methods are recognized and supported.

At present, in higher education, the assessment of study directions (study programs) is carried out in conformity with the Cabinet Regulation No. 407 (14/07/2015) "Regulations for the Accreditation of Higher Education Institutions, Colleges and Study Directions" (2015) that provides for the quality criteria in conformity to which a higher education institution, a college and a study direction shall be assessed. In order to ensure quality in higher education it is important to develop internal quality assurance system at every educational institution, where could be, for example, four main directions identified: internal quality assurance system, standards applied and their interaction, implementation and documents, and, finally, the benefit gained as a result of the implementation of internal quality management system.

As already mentioned, the concept of quality is, in fact, mostly connected to the manufacturing industry and the quality in the commercial context is related to the usefulness and safety of the product. In relation to education, educational quality is a very widely used concept that is applied to identify practically all fields, functions, processes, and phenomena related to education. For this reason, educational quality concept is rather non-specific and vague, which makes it difficult to develop particular criteria. When applying the quality concept to the educational context, it may be defined as a totality of indications and qualities developed during the educational process. Such totality is characterized by compliance of educational process and the management of educational institution to the previously set and envisaged requirements. But in the explanatory dictionary of pedagogical terms, the quality concept is viewed within the context of pedagogical process and, when defining the concept "educational quality", the successive interconnected quality of study process and result has been emphasized. However, R.Vira (2001), when describing the concept of educational quality, emphasizes the process, pointing out not only the compliance of the study process to but also the conformity of the activities of the management of an educational institution to the previously set and envisaged requirements.

Having analysed the opinions of various authors, we can observe that it is possible to identify two different possibilities how to ensure quality: by focusing on the process, and by focusing on the result. However, it follows from the educational quality definitions, laws and regulations that the process and the result are emphasized.

While focusing on the process and results, it is also important to pay attention to the compliance. By the concept "compliance" there is meant the comparison of two values, for example, products/processes/systems and the initial requirements set for them or the requirements stipulated in the laws and regulations. The evaluation of compliance according to its broader meaning is any activity the aim of which is to determine whether the requirements set for the product/the process/the system have been met. It is clear that accreditation is one of the fields of the assessment of compliance. The Education Law (1999) provides that in the 
course of accreditation, the quality of the implementation of the relevant educational program shall be evaluated. But the Law on Institutions of Higher Education stipulates that "accreditation of the study direction is an inspection with the purpose of determining the quality of the resources of an institution of higher education or a college and the ability to implement a study program corresponding to a specific study direction in accordance with regulatory enactments. The accreditation of the study direction of an institution of higher education or a college gives the institution of higher education or a college the right to issue a state-recognised diploma of higher education for successful acquisition of a study program corresponding to the relevant study direction", the procedure for the accreditation of study directions is provided in the Cabinet Regulation No. 407 (14/07/2015) "Regulations for the Accreditation of Higher Education Institutions, Colleges and Study Directions" (2015).

In order to evaluate the quality of higher education, the Baltic International Bank Latvia (2017) carried out a study where it was established that $28 \%$ of Latvia's residents have found that during the last years, the quality of education in the country has changed for worse. At the same time, within the study performed, most of the respondents or $40 \%$ (a year ago - 37\%) pointed out that during the last years, the quality of education in the country has neither improved, nor changed for worse, $16 \%(18 \%)$ expressed a point of view that it is possible to observe an improvement, and for $16 \%(17 \%)$ of respondents it was difficult to answer this question. According to the data of the latest survey, the residents of Latvia become increasingly critical about the readiness of educated specialists for the labour market, i. e., during the survey, $42 \%$ of residents agreed to the statement that the qualification of the graduates of educational institutions is not sufficient, while $38 \%$ expressed a view that the educational system of Latvia does not react to the actual demand of labour market, but $36 \%$ pointed out that the educational system educates specialists who, in order to commence their professional career, need to improve their professional skills.

In order to facilitate the improvement of the quality of higher education in Latvia, according to the residents' opinion, it is equally important to make amendments to the content of study programs (32\%) and to introduce stricter requirements for the teaching staff by assessing their qualification more carefully (32\%). Also, but to a lesser degree, the respondents have emphasized the necessity to provide students with more practice opportunities $(29 \%)$ and to allocate more funds for the needs of higher education $(26 \%)$ at the state level. In comparatively less cases, the respondents have pointed out that the assistance shall be searched in foreign countries, for example, by attracting independent foreign experts for the accreditation of higher education programs $(5 \%)$.

Sustainable Development Strategy of Latvia until 2030 (2010) provides that "It is the quality of education that is very important for specification of life and work opportunities of a person in Latvia. Upon emerging of education market, access to higher levels of education is determined by the ability or inability of families to pay for the relevant education. The correcting role of the public sector is very important in this case, levelling out the possibilities of people to acquire education and appropriate qualification." 
In the Standards and Guidelines for Assurance of Quality in the European Higher Education Area (2015) it is also emphasized that in order to achieve the desirable quality and compliance in higher education, it is necessary to achieve that students as well as employers and wider community would be interested in qualitative higher education.

\section{DISCUSSION}

Section 28 of the Law on Administration of Residential Houses (2010) stipulates the persons who are entitled to practice the administration and management of the joint property of the apartment house. It is necessary to analyse the words "administration", "management", and "an administrator of a residential house". No regulatory enactment in force provides the explanation of the concepts "administration" and "management". Section 4 of the Law on Administration of Residential Houses (2010) provides the list of principles of for the administration of a residential house. In the Latvian language vocabulary (2006), the word "to manage" means 'to have a good knowledge of' and 'to work on'; the meaning of the expression "to have a good knowledge" is "to know, to be acquainted with something all-in-all', and the meaning of "to work on" - 'to modify within the labour process, to develop, arrange according to the preliminary plan, to change, to adjust and to improve'. Thus, we can see that the management comprises both the necessity for a certain volume of knowledge about a thing and particular actions that, in case of management, do not limit only by ensuring that the condition of the thing does not change for worse but indicate that there shall be taken active measures. "To administrate" means "to direct the operations of something by having command over it' (Latvian language vocabulary, 2006). In the Economic Explanatory Dictionary (Economic Explanatory Dictionary, 2000), the word "administration" is explained as "supervision of an object, running according to the owner's aims, strategy". In other words, administration is the implementation of the owner's will. Consequently, as mentioned above, the owner's will to administer and manage the undivided shares of a joint property may be performed by the owner or the administrator of a residential house. Law on Administration of Residential Houses (2010) provides that "a residential house owner is a residential house owner or a possessor of a State residential house; the residential house owner is also the apartment property owner. But an administrator is an adult natural person with the capacity to act or a legal person, who on the basis of an administration contract performs the administrative activities assigned by the owner of the residential house."

In relation to the administration of residential houses, there has been adopted an essential regulatory enactment - the Law on Administration of Residential Houses (2010) -, which came into force on 1 January 2010. Section 6 of the Law stipulates the activities that shall be performed in relation to the administration of a residential house, i. e., the mandatory administrative activities shall be as follows:

1) "the maintenance (physical preservation) of the residential house in accordance with the requirements of laws and regulations: the sanitary servicing of the residential house; the supply of thermal energy; provision of 
water supply and sewerage, as well as removal of household waste; the inspection, technical servicing and current repairs of the residential house, the facilities and communications located therein; the provision of the requirements set out for the residential house as an environmental object;

2) the planning, organisation and supervision of administrative work, including: the preparation of an administrative work plan, including a plan of measures necessary for the maintenance, the preparation of the relevant annual draft budget; the organisation of financial accounting; keeping of the file of the residential house; entering into a contract with the owner of the land parcel regarding the use of the land attached to a residential house; the provision of information to the state and local government institutions."

It is obvious from the above mentioned that the residential house administrator shall perform a great volume of responsible work. In order the administrators of residential houses could perform the administration and management of residential houses in conformity with the provisions of regulatory enactments, the Law on Administration of Residential Houses provides for the requirements regarding the professional qualification of a residential house administrator. Section 13 of the Law stipulates two types of professional qualifications: a house administrator, and a house manager. In order to become a house administrator, a person shall obtain the fourth level of professional qualifications. The fourth level of professional qualifications can be obtained after two-year studies in the corresponding college study program. In order to become a house manager, a person shall obtain the third level of professional qualification. The third level of professional qualification can be obtained after attending a sixmonth vocational continuing education course.

The basic tasks of the profession and the basic requirements set for the qualification are provided by the Cabinet Regulation No. 264 (23/05/2017) "Regulations on the Profession Classificator, the Basic Professional Tasks and the Basic Requirements for the Qualification" (2017). Before this Regulation came into effect (01/06/2017), the valid regulatory enactment was the Cabinet Regulation No. 461 (18/05/2010) "Regulations on the Profession Classificator, the Basic Professional Tasks and the Basic Requirements for the Qualification" (2017), and the "Procedure for the Use and Actualization of Profession Classificator" (2010). This Regulation also provided for the corresponding basic professional tasks and the basic requirements. By the respective Cabinet Regulation, there was approved also the standard of profession, namely, the standard for the profession of an administrator of houses, which provided job description, the professional competences necessary for performing the professional activities, the skills necessary for the fulfilment of the basic tasks of professional activities, and the knowledge necessary for the fulfilment of the basic tasks of professional activities. It should be pointed out that the Regulation in force does not comprise the previously approved standard of profession, which enables to improve and adapt the standard in conformity with the real labour market demands.

When developing study programs, educational institutions take into consideration not only the regulatory enactment of the educational field but also 
the standard of the respective profession. The compliance to the standard of the profession is an essential criterion for the assessment of the quality of a study program. Paragraph 18.2 of the Cabinet Regulation No. 407 (14/07/2015) "Regulations for the Accreditation of Higher Education Institutions, Colleges and Study Directions" (2015) provides for the compliance of the content of a study program to the standard of the profession as one of the requirements set for the description of a study program. Also, when evaluating the study program, one of the assessment criteria in the expert's questionnaire is "whether the content of the study program corresponds to the degree to be obtained, degree and professional qualification (the standard of the profession), as well as to the framework requirements of the qualification".

Having acquainted with the standard for the profession of an administrator of houses (approved by the Cabinet Regulation No. 461 (18/05/2010)) and the respective credit points to be obtained as a result of a two-year study period, i. e., 80 credit points, we can see that that the standard provides for incommensurable knowledge for the fulfilment of basic tasks, while performing professional activities. Besides, it should be taken into account that this concerns the middle level specialist. It means - in conformity with the standard of the profession, the administrator of houses, for the fulfilment of basic tasks, while performing professional activities, shall know (at the level of understanding) the professional terminology in the state language and in two foreign languages, and, in addition, for the fulfilment of basic tasks, while performing professional activities, shall know (at the user's level) the state language and two foreign languages at the communication level. We should mention also the European law regarding the administration of houses. It is clear that one can always master more and more knowledge, but, when an educational institution is developing a qualitative study program demanded in the labour market, the main attention shall be paid to ensuring the professional studies, not to the teaching of a foreign language.

Within the framework of discussion, the attention shall be paid also to the Regulation regarding the State Standard for First Level Professional Higher Education (2001), which provides for the division of program credit points, i. e., out of the 80 credit points of the program volume, 56 credit points are envisaged for the study courses, out of which at least 20 credit points shall be obtained for general education training courses and 36 credit points - for sector training courses. Accordingly, out of the total number of credit points envisaged for the study course, only $64 \%$ are planned for sector training courses and $36 \%$ are planned for the general education training courses.

At the same time, in the standard for the profession of an administrator of houses for the fulfilment of basic tasks, while performing professional activities, there have been included 28 knowledge positions at the level of knowledge application and at the level of understanding, but for the fulfilment of basic tasks, while performing professional activities, there have been included four knowledge positions at the level of a percept.

Having examined the requirements of the State Standard for First-Level Professional Higher Education and the standard of the profession of an administrator of houses, in conformity with these requirements, the study 
programs shall comprise a sufficient volume of knowledge for performing the basic tasks of professional activities. In the higher education area of Latvia, the administrators of houses are educated at the College of Law, Riga Technical University, Jekabpils Agrobusiness College, and at all educational institutions the study program has an equal total volume of credit points, i. e., 80 credit points.

The data of the employers' survey carried out in September 2017 on the professional preparedness of house managers, their knowledge and competences, indicate that $31 \%$ of the respondents consider that training of house managers, their professional knowledge, skills and competences at the professional education study program correspond to the employers' needs partially, $26 \%$ - to a large extent, and $8 \%$-does not correspond (Fig. 1).

Conformity of the graduates' professional knowledge, skills and competences at the house managers professional study program to the needs of companies

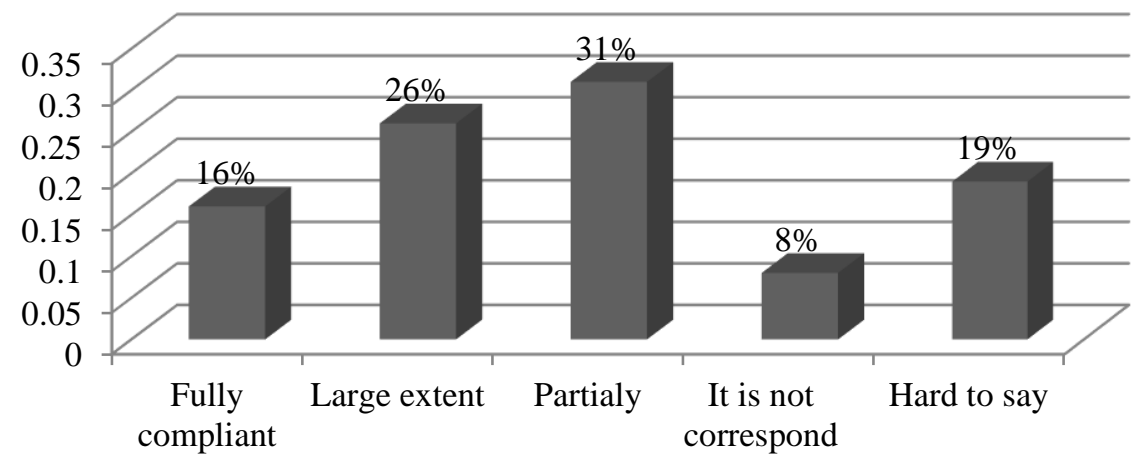

Fig. 1. Conformity of the graduates' professional knowledge, skills and competences at the house managers' professional study program to the needs of companies.

Regarding the higher education graduates, the employers have indicated in the survey that they are mostly satisfied with the graduates' knowledge and competences. In addition the employers expect more knowledge and skills in technical issues (related to the inspection of buildings, reading of construction projects, management plans, etc.), expect grater interest in the latest industry trends not only in Latvia but also in the world, knowledge of planning, in-depth knowledge of new materials and technologies, as well as ability to argue and defend their ideas, and not less important, to express the principles and rules of use of the Latvian flag. Employers have also emphasized that if the house manager is not competent and does not know the technical issues, then it is necessary to attract an additional specialist from the side, which is financially unprofitable and, at the same time, the is not able to perform his duties properly, i. e., to participate in general meetings, to deal with topical issues.

Now, the first-level professional higher education and professional qualification can be obtained at three accredited higher education institutions (data 
from the AIC and NIID): the College of Law (JK), Jekabpils Agrobusiness College (JAK), and Riga Technical University (RTU) (Table 1).

Table 1. Higher education institutions and study programs for the acquisition of house manager's professional qualification

\begin{tabular}{|l|l|r|l|}
\hline \multicolumn{1}{|c|}{$\begin{array}{c}\text { Higher education } \\
\text { institution }\end{array}$} & \multicolumn{1}{|c|}{ Study program } & $\begin{array}{c}\text { Study program } \\
\text { length / CP }\end{array}$ & \multicolumn{1}{c|}{$\begin{array}{c}\text { Acquired } \\
\text { professional } \\
\text { qualification }\end{array}$} \\
\hline College of Law & $\begin{array}{l}\text { Real estate management } \\
\text { and administration }\end{array}$ & 80 & House manager \\
\hline $\begin{array}{l}\text { Jekabpils } \\
\text { Agrobusiness } \\
\text { College }\end{array}$ & House management & 80 & House manager \\
\hline $\begin{array}{l}\text { Riga Technical } \\
\text { University }\end{array}$ & $\begin{array}{l}\text { Real estate property } \\
\text { management }\end{array}$ & 80 & House manager \\
\hline
\end{tabular}

Analysing the study programs of all three higher education institutions (data obtained from the AIC) and their compliance with the profession standard, it can be seen that none of the study programs has been fully developed (Fig. 2) taking into account the requirements of the profession standard. This has its own explanation, which in large is related to the fact that the labour market requires many kinds of professional knowledge and competences that are not included in the profession standard, for example, there may be mentioned additional knowledge in engineering communications, fire safety, economic activities, real estate transactions, etc., which are included in the study programs.

Conformity of the graduates' professional knowledge, skills and competences at the house managers professional study program to the needs of companies (author's calculation)

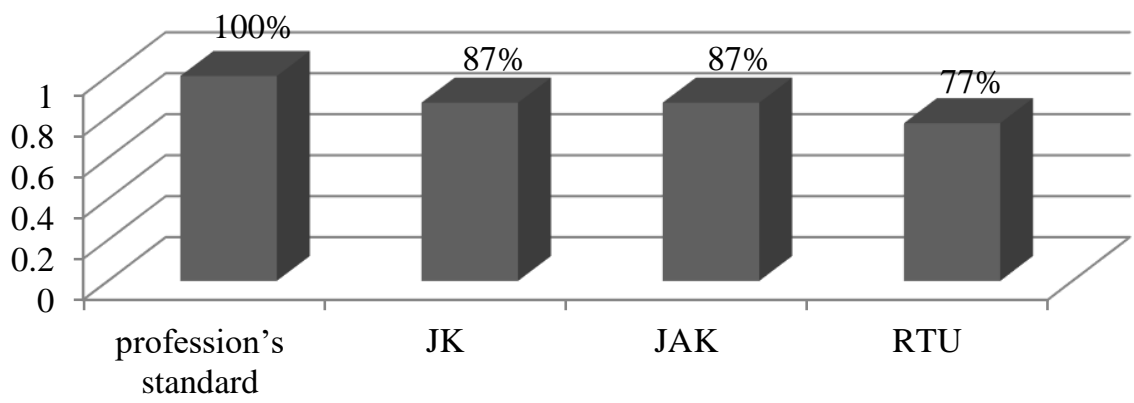

Fig. 2. Compliance of the content of the study program to the profession's standard (the author's calculation).

Employers (81\% of the respondents) also noted in the questionnaire that it is inappropriate to make harder the content of the studies by teaching a number of foreign languages and professional terms in foreign languages as required by the 
profession standard, but more attention should be paid to the technical study courses as mentioned before.

The educational standard to some extent limits the possibilities of educational institutions to freely form their study programs and to determine the distribution of study credit points. Students also indicated this restriction. The students surveyed (September, October 2017) have explained that there is no need for such a large number of credit points for comprehensive study courses, which take a large part of the study program; more study courses should be provided for the acquisition of professional knowledge, real situations, discussions. In addition to what the employers indicate, students offer to supplement the study program with professional knowledge on the technology of buildings and structures, repair and renovation of the engineering communication technologies, technical documentation of objects, technological processes of construction work, disinsection and disinfection services, etc.

Evaluating the quality of the professional higher education, the Baltic International Bank carried out a survey, where the major part of respondents (32\%) indicated that that the improvement of the quality of higher education requires changes in the study programs, particularly in their content. The Baltic International Bank has carried out a study on the quality of higher education also in 2013, and the data compared with 2017, show that there has been an increase in the number of respondents who believe that it is important to make changes in study programs in order to ensure higher education quality, its content, in 2013: $29 \%$ of respondents and in 2017: $32 \%$ of respondents. Although the study was conducted mostly on the quality and relevance of higher education, at the same time it is clearly applicable also to first-level professional higher education programs, including programs for the training of house managers. The study reflects the general trend in the higher education space.

Short-cycle professional higher education in the field of real estate management attracts both employees who plan to work as house managers and employers who are already active in this sector, since in a relatively short time, it is possible to obtain first-level professional higher education (in Latvia) and the professional qualification of a house manager, which allows competing successfully in the labour market. In the field of real estate management, the importance of education is related to such factors as the development of knowledge and skills in the process of real estate management and the strengthening of psychological skills that are essential for the employees of this sector (Pukīte, Stāmure, \& Geipele 2016).

Most of the educational institutions have aligned their study programs to the developed standard of profession and to the standard of professional higher education, but at the same time, having evaluated the requirements stipulated in the Law on Administration of Residential Houses regarding the professional activities of a house administrator, we should point out that both the standard of profession and the study programs developed by educational institutions to great extent comprise the positions that are not topical and because of which it is not possible to acquire a greater volume of knowledge related to the profession. 


\section{CONCLUSION}

When evaluating the readiness of the administrators of houses (their competences, skills and knowledge), initially the quality of the study program is assessed, and then the feedback is the assessment provided by employers. When evaluating the study program for the education of professional administrators of houses, one of the criteria for the assessment of the quality is the compliance of the content of the study program to the degree to be obtained, the degree and professional qualification, and compliance with the standard of the respective profession. In the respective standard for the profession of an administrator of houses, incommensurable competences and skills of an administrator of houses have been included and not corresponding to the Law on Administration of Residential Houses and the Law on Residential Property (2010). Since 1 June 2017, a new regulation has come into effect regarding the Profession classificator, the basic tasks corresponding to the profession and the basic qualification requirements, where only the basic tasks of separate groups are disclosed; however, there is no separate standard for the profession of an administrator of houses. In this case, it is possible, using the appropriate approach, to bring order into this sphere by revising the standard of the profession taking into consideration the binding laws and regulations that provide for certain competences and skills of an administrator of houses. It is important to include into the working group that develops the standard of the profession the representatives of those higher education institutions, the directors of the respective study programmes, who will implement the study programs for the education of house administrators. And, the next step is the revision of the division of study courses according to the credit points divided between the general education training courses and the sector training courses, which is provided by the State Standard for First-Level Professional Higher Education.

\section{REFERENCES}

Academic Information Centre. (2015). Akreditētie studiju virzieni un programmas [Accredited study directions and programs]. (2017). Retrieved October 17, 2017 from http://www.aic.lv/portal/aikna/akreditetie-studiju-virzieni-un-programmas

Baltic International Bank Latvia. (2017). Augstākās izglītības kvalitāte [Higher education quality]. Retrieved October 17, 2017 from https://www.bib.eu/uploads/2017/08/Izglitiba-BalticInternational-Bank-Latvijas-barometrs-Julijs-2017.pdf

Course BB. (2017). Comparision Paper. Retrieved October 1, 2017 from https://www.coursebb.com/2017/01/09/compare-and-contrast-dr-w-edward-demings-dr-philipb-crosby-and-dr-joseph-m-juran/\#_Toc437695285

Crosby, P. B. (1979). Quality Is Free: The Art of Making Quality Certain. McGraw-Hill, p. 309.

Deming E.W. (2017). Vyhod iz krizisa: Novaja paradigma upravlenija ljudmi, sistemami $i$ processami. [The paradigm of managing people, systems and processes]. Moscow: Alpina Pabliser, 2017.

Economic Explanatory Dictionary. (2000). Rīga: Izdevniecība Zinātne, p 702.

European Commission. (2008). European Qualification Framework Level 5. Retrieved September 27, 2017 from http://ec.europa.eu/eqf/compare/eqf_en.htm\#comparison

European Commission. (2017). Quality and relevance in higher education. Retrieved September 27, 2017, from https://ec.europa.eu/education/policy/higher-education/quality-relevance 
Eurashe. (2010). L5 Missing - Level 5 the Missing link. Short cycle Higher Education in Europe. Retrieved September 12, 2017 from https://www.eurashe.eu/projects/15missing/

Harvey, L., \& Green, D. (1993). Defining Quality. Assessment \& Evaluation in Higher Education, 18(1), 9-34. https://doi.org/10.1080/0260293930180102

International Organization for Standardization. (2008). ISO 9000 - Quality management. (Standart ISO 9001:2008). Retrieved October 17, 2017, from http://www.iso.org/iso/home/standards/management-standards/iso_9000.htm

International Organization for Standardization. (2000). ISO 9000 - Quality management. (Standart ISO 9001:2000). Retrieved October 17, 2017, from https://www.iso.org/iso-9001-qualitymanagement.html

Ishikawa, K. (1988). Japonskie metody upravlenija kacestvom [What Is Total Quality Control? The Japanese Way]. Moscow: Ekonomika, p. 199.

Juran, J. M. (1974). Juran's Quality Control Handbook. NewYork: McGraw-Hill.

Latvian language vocabulary. (2006). Riga: Izdevniecība Avots, p. 1210.

Legislation of the Republic of Latvia. Cabinet of Ministers ordinance Nr. 407. (2015). Augstskolu, koledžu un studiju virzienu akreditācijas noteikumi [Regulations for the Accreditation of Higher Education Institutions, Colleges and Study Directions]. The official Publisher of the Republic of Latvia: Latvijas Vēstnesis, no.146, 2015.

Legislation of the Republic of Latvia. Cabinet of Ministers ordinance Nr. 141. (2001). State Standard for First Level Professional Higher Education: Latvian Journal, no. 54, 2001

Legislation of the Republic of Latvia. Cabinet of Ministers ordinance Nr. 640. (2014).Latvijas augstākās izglītības ārējās izglītības kvalitātes nodrošināšanas sistēmas pilnveide [Improvement of the quality assurance system of higher education in Latvia]. Retrieved September 28, 2017, from https://likumi.lv/doc.php?id=270048

Legislation of the Republic of Latvia. Cabinet of Ministers ordinance Nr. 264. (2017). Noteikumi par Profesiju klasifikatoru, profesijai atbilstošiem pamatuzdevumiem un kvalifikācijas pamatprasībām [Regulations on the Profession Classificator, the Basic Professional Tasks and the Basic Requirements for the Qualification]. Retrieved October 2, 2017, from https://likumi.lv/doc.php?id=291004

Legislation of the Republic of Latvia. Cabinet of Ministers ordinance Nr. 461. (2010). Noteikumi par Profesiju klasifikatoru, profesijai atbilstošiem pamatuzdevumiem un kvalifikācijas pamatprasībām [Regulations on the Profession Classificator, the Basic Professional Tasks and the Basic Requirements for the Qualification]. Retrieved October 2, 2017, from https://likumi.lv/doc.php?id=210806

Legislation of the Republic of Latvia. (1992).Civil Law. Retrieved October 17, 2017, from https://likumi.lv/doc.php?id=90221

Legislation of the Republic of Latvia. (1993). Constitution of the Republic of Latvia. Retrieved October 1, 2017, from https://likumi.lv/doc.php?id=57980

Legislation of the Republic of Latvia. (1999). Izglititibas likums [Education Law]. Retrieved September 28, 2017, from http://likumi.lv/ta/id/50759-izglitibas-likums

Legislation of the Republic of Latvia. (1999). Profesionālās izglītības likums [Vocational Education Law]. Retrieved September 28, 2017, from http://likumi.lv/doc.php?id=20244

Legislation of the Republic of Latvia. (2010). Dzīvojamo māju pārvaldīšanas likums [Law On Administration of Residential Houses]. Retrieved October 2, 2017, from http://likumi.lv/ta/id/193573-dzivojamo-maju-parvaldisanas-likums

Legislation of the Republic of Latvia. (2010). Dzīvokḷa ippašuma likums [Law on Residential Property]. Retrieved October 2, 2017, from https://likumi.lv/doc.php?id=221382

Liu, C.-T., Guo, Y. M., \& Lee, C.-H. (2011). The effects of relationship quality and switching barriers on customer loyalty. International Journal of Information Management, 31(1), 71-79. https://doi.org/10.1016/j.ijinfomgt.2010.05.008

Lūce, I. (2017). Short Cycle Higher Education Development in Latvia. Current Business and Economics Driven Discourse and Education: Perspectives from Around the World BCES Conference Books, (pp. 245-251). Sofia: Bulgarian Comparative Education Society.

Post, M. (2014). Definitions of Quality of Life: What Has Happened and How to Move On. Topics in Spinal Cord Injury Rehabilitation, 20(3), 167-180. https://doi.org/10.1310/sci2003-167 
Puḳite, I., Stāmure, I., \& Geipele, I. (2016). Capacity of Professional Specialists in Residential Housing Management in Latvia. Baltic Journal of Real Estate Economics and Construction Management, 4(1), 100-115. https://doi.org/10.1515/bjreecm-2016-0008

Standards and Guidelines for Assurance of Quality in the European Higher Education Area. (2015). Retrieved December 11, 2017 from http://www.enqa.eu/wpcontent/uploads/2015/11/ESG_2015.pdf

Sustainable Development Strategy of Latvia until 2030. (2010). Retrieved January 14, 2018 from https://www.cbs.nl/NR/rdonlyres/B7A5865F-0D1B-42AE-A838-

FBA4CA31674D/0/Latvia_2010.pdf

Vira, R. (2001). Kvalitātes vadības sistēmas ieviešanas izpēte augstskolā [Investigation of introduction of quality management system at the university]. (Doctoral dissertation, University of Latvia). p. 190.

\section{AUTHORS' SHORT BIOGRAPHY}

Intra Lūce, Mg. iur., Mg. oec., is a PhD student of the Faculty of Education, Psychology and Art of the University of Latvia. She is a Docent and the Deputy Director of the College of Law and the Head of the Council of College of Law Her current research area is the development and future of short-cycle higher education (SCHE) in Latvia. She has experience in the development and evaluation of study programs. I. Lūce is a Board Member of the EURASHE, the PRME Chapter for the Central and Eastern Europe region, and the FIABCI-Baltic Multinational Chapter. 